NON-STATUS WORKERS AND THE OFFICIAL DISCOURSE IN CANADA:

\title{
A CASE OF CONVENIENCE.
}

\author{
by
}

Cristina Bidone-Kramer, MBA, UFRGS, Brazil, 1996

\author{
A Major Research Paper \\ Presented to Ryerson University \\ in partial fulfillment of the requirements for the degree of
}

Master of Arts

in the Program of

Immigration and Settlement Studies

Toronto, Ontario, Canada, 2011

(c) Cristina Bidone-Kramer 2011 
I hereby declare that I am the sole author of this major research paper.

I authorize Ryerson University to lend this paper to other institutions or individuals for the purpose of scholarly research.

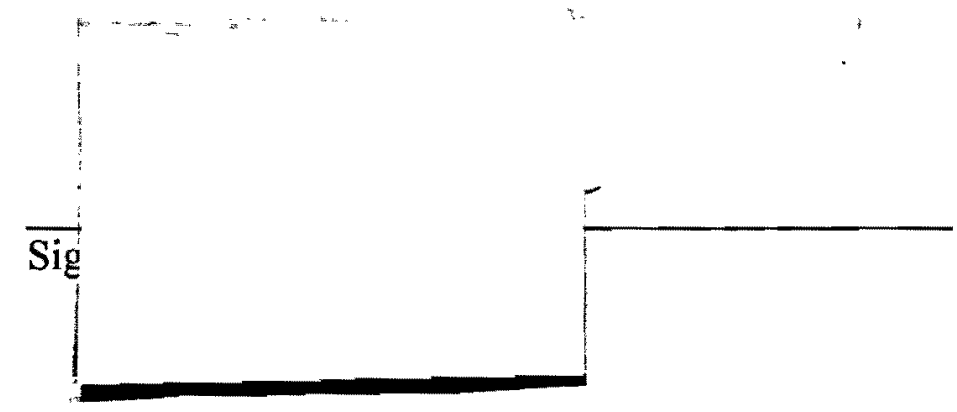

I further authorize Ryerson University to reproduce this paper by photocopying or by other means, in total or in part, at the request of other institutions or individuals for the purpose of scholarly research.

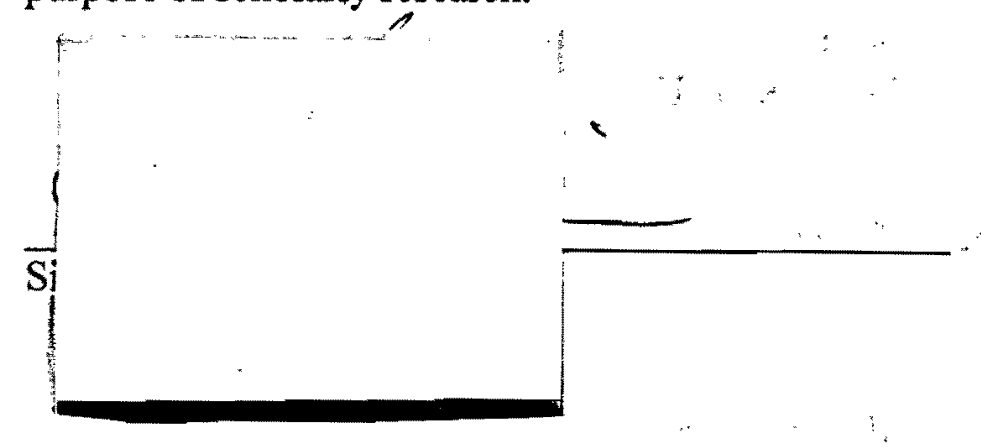


NON-STATUS WORKERS AND THE OFFICIAL DISCOURSE IN CANADA: A CASE OF CONVENIENCE

\author{
Cristina Bidone-Kramer \\ Master of Arts, 2011 \\ Immigration and Settlement Studies \\ Ryerson University
}

\title{
ABSTRACT
}

This paper makes a critical assessment of the study conducted by the CIMM (Standing Committee on Immigration and Citizenship) on undocumented and temporary foreign workers. It examines records of three moments of the process: (i) minutes of meetings during the assessment phase; (ii) the CIMM Report; (iii) and the Government Response. The argument sustained throughout the paper is that government's negative representation of non-status workers is conveniently constructed to avoid policy changes and consequently sustains the irregular movement of migrants.

Key words: non-status workers, irregular migration, Foucault, non-status representation 


\section{Acknowledgment}

I would like to thank my supervisor, Prof. Vappu Tÿÿska. She diligently went through numerous reviews and her constant guidance and constructive feedbacks were key to the completion of this work. I am very grateful for her extended support during the whole program.

I would also like to thank Prof. Harald Bauder for his valuable feedbacks during the earliest version of this work and more recently as the second reader.

\section{Dedication}

To Ronald and Karina, for their unconditional love and support. 


\section{Table of Contents}

1. Introduction

1.1. Definitions \& Limitations

1.2 Research Problem Description

2. Literature Review

2.1 Non-Status Migration: a growing global Phenomenon

2.2 Problems posed by Non-Status Migration

2.3 Perspectives on Irregular Migration

2.4 Non-Status Migration in Canada

2.4.1 Pathways Leading to Non-Status

2.4.2 Living as Non-Status

3. Analytical Framework: A Foucauldian Approach on Non-Status Migration

3.1 Power

3.2 Processes of Objectification

3.3 Discourse

4. Research Methods

5. Analysis

5.1 Preliminaries of the CIMM Study

5.2 First Meeting: Official Discourse \& Party Ideologies

5.3 CIMM Report

5.4 Government Response

6. Discussion and Conclusion

7. References 


\section{Introduction}

Non-status migration is a global issue and a source of continuous political concern with "no end in sight" (Papademetriou, 2005, p.1). In Canada, the non-status population is estimated to be half-a-million and its increase tendency is aligned to growing of Temporary Foreign Workers Program (TFWP) (Hennebry, 2010). However, despite its importance and apart from a few exceptional episodes ${ }^{1}$, irregular migration is still not part of the national public debate, something that led Goldring et al. (2009) to conclude that "in Canada, migrant illegality is largely a non-issue" (p. 240). In releases from Citizenship and Immigration Canada, irregular migration is approached from a criminal or risk perspective with reference made concurrently to human trafficking, terrorism and border control.

Considering both the dearth of debate and choice of themes in the public debate, the study conducted by the Standing Committee on Immigration and Citizenship (CIMM) on undocumented and temporary foreign workers represents a unique opportunity to understand the official representation of undocumented migration in Canada. It also allows for an "insider perspective" of the discussion on the issue by politicians and government representants. The relevance of this approach is justified by the influence exercised by official public discourse on population's opinion, as pointed out in Menjívar \& Kil (2002):

(...) official cues are a key influence in public opinion on social issues. Public officials' discourse on immigrant related issues can thus powerfully affect the lives of immigrants (p, 160).

\footnotetext{
${ }^{1}$ Arrival of boats with unauthorized refugees in B.C. shores, deportations cases, discussion of refugees' validity claims, and activist campaigns (Goldring et al., 2009).
} 
This paper makes a critical assessment of the study conducted by the CIMM on undocumented and temporary foreign workers using elements of Foucault's social theory to support the analysis. Public records of three moments of the CIMM study are examined: (i) minutes of meetings of the study's assessment phase; (ii) CIMM report (Report, 2009); and (iii) the government reply (Government of Canada Response, 2009). The argument sustained in the paper is that government's negative representation of nonstatus workers is conveniently constructed to avoid policy changes and consequently sustains the irregular movement of migrants.

\subsection{Definitions \& Limitations}

Terms currently referred in the literature to designate people lacking legal migratory status - non-status, undocumented, unauthorized, irregular, and out-of-status as well as their variants applied to migration (e.g. non-status migration) are employed interchangeably in this paper. They refer to the definition of undocumented workers offered in Magalhães et al. (2009):

Women and men who participate in the Canadian labour force by legally entering the country and (a) not respecting the limits of their visa or (b) over staying their visa permitted time, as well as by illegally entering the country, including those smuggled across the border (n.p.).

It is acknowledged that non-status workers form a heterogeneous group in terms of experience and education. In this paper, however, the representation of non-status individuals will follow the tendency highlighted in the literature where non-status 
workers are mostly considered low-skilled workers ${ }^{2}$. This limitation is necessary to sustain the argumentation that irregular migration is triggered by the lack of legal channels linking temporary work with permanence in Canada.

Also, despite the several ways leading to out-of-status conditions in the literature, this paper will emphasize the route provided by Temporary Foreign Work Programs, specifically programs for low-skilled workers, this association having been established by the CIMM study

\subsection{Research Problem Description}

In 2008 the Standing Committee on Citizenship and Immigration (CIMM) was commissioned by the House of Commons to investigate the situation of temporary foreign workers and non-status workers in Canada due to the allegation that labor needs across the country were been addressed by these workers. For almost three weeks in 2008 the Committee traveled to 12 cities across Canada gathering material and testimonies to assist it to understand issues involving temporary and nonstatus workers. More than 50 testimonies were heard and hundreds of briefs from diverse organizations were received (Report, 2009). Results from this process led the Committee to conclude that, in fact, temporary foreign worker programs were used for purposes different from what they were originally designed for, due to a combination of labor shortages in certain areas of the country, and immigration constraints. Instead of fulfilling seasonal or temporary labour shortages, temporary programs were used to attend to long-term labor needs and bring to Canada workers otherwise not available under the economic stream of

\footnotetext{
${ }^{2}$ Categories $\mathrm{C}$ and $\mathrm{D}$ of the National Occupational Classification (NOC) established by Human Resources and Skills Development Canada (HRSDC) - http://www5,hrsdc.gc.ca/noc/english/noc/2006/pdf/Matrix.pdf
} 
immigration, due to large time delays in application processing or lack of worker qualifications in this stream.

The quality and quantity of evidences made available to CIMM led it to conclusive observations about the situation of non-status workers. Particularly significant were: the general understanding of demand for unskilled work in the long-term; the insufficiency of the immigration programs to provide for this demand; and the deficiency of authorized venues for temporary workers to remain permanently in Canada. These observations, however, were not enough to unify the CIMM members towards supporting an amnesty program for people currently under an irregular status situation in Canada. Justifying the impossibility to "solve the problem" (p. 49) of non-status migration due to the "complex and multifaceted" (p. 49) character of the issue, the Committee limited its recommendations of measures aiming to intercept the growing of non-status migration in Canada to: (i) the creation of pathways for permanence of temporary workers; (ii) review of the points system; and (iii) enforcing the role of Provincial Nominee Programs.

A CIMM report summarizing these findings and providing recommendations to improve TFWPs was delivered to the House of Commons with a requested for a government response to the recommendations. It went to Citizenship and Immigration Canada (CIC) which formulated a reply in its Government of Canada Response document (2009). Regardless of strong evidence by the Committee favorable to non-status migrants, the government refused to regularize "those who failed to respect the terms and conditions of the program and remained in Canada through illegal avenues" (p. 11), in a fashion that associates non-status condition with poor character and criminal attitudes. The government also refused to create pathways linking the temporary program with 
permanent residence besides the one existing through the Provincial Nominee Program (PNP), justifying it by a claim that low-skilled workers would have problems adjusting to the Canadian labor market due their lack of education, training and language skills (Government of Canada Response, 2009). 


\section{Literature Review}

\subsection{Non-Status Migration: A Growing Global Phenomenon}

On a global scale, it is estimated that the non-status population comprises 15 to 20 percent of the world's total immigrant stock; involving 30 to 40 million people (Papademetriou, 2005). The largest concentrations of irregulars are in the USA, South Africa, and Continental Europe. The population in Canada is believed to be half-a-million (Papademetriou, 2005).

Considering all variants of the phenomenon, irregular migration is a global reality, including retirees living without authorization in developing countries, and categories of people who temporarily or permanently fall out of status due to backlogs, government rules and bureaucracies (Papademetriou, 2005).

In the USA, Ettinger (2009) was able to trace the origins of the irregular movement back to the mid-1880s. This happened when new routes into the US through Canadian and Mexican borders were pioneered by immigrants wishing to circumvent immigration barriers placed on American ports. The restrictions, in this case, were directed towards "paupers, convicts, the mentally infirm, Chinese workers, and workers under contract" (p. 11). Ettinger (2009) draws a direct association between increases of restrictions and the origins of unauthorized border-crossing, characterizing non-status movement as one of defiance to "state power over human mobility" (p. 8).

Although not new, irregular migration only gained notoriety during the last two decades when became the fastest growing mode of migration worldwide (Papademetriou, 2005). In Europe, for example, the insurgence of irregular movement is related to the end 
of communist regimes occurred over a period of slow economic triggered by the 1973 oil crisis where the only work available was in "labour market sectors characterized by temporariness, instability, low skills, low pay and difficult working conditions" (Triandafyllidou, 2010, p. 11). The further establishment of the European Union (EU) released human movement intra-EU countries from its illegal characterization. Nonetheless, flows coming from Eastern Europe, Sub-Saharan Africa, Southeast Asia and China motivated by warfare and poverty are the new facet of the irregular movement (Triandafyllidou, 2010).

Increased global mobility facilitated by the expansion of air transportation, the reconfiguration of global economy, displacement of marginalized populations due to economic disparities and armed conflicts, and awareness of better opportunities are factors cited in Kapur (2003) to explain the raise of migration, including its unauthorized form. The United Nations' Human Development report (UNHD, 2009) attributes the increase of irregular migration to two factors: (i) the entry policies of receiving countries restricting access of low-skilled workers and (ii) heightened border controls. The report (UNHD, 2009) emphasizes the current demand for low-skilled workers and entry policies that overly restrict their entry by saying that such policies create "denial and delay" (p. 95) in labor needs, worsening the situation of non-status workers.

\subsection{Problems Posed by Non-Status Migration}

Papademetriou (2005) contends that governments need to deal with irregular immigration because it "subverts a society's legal order and undermines or perverts a variety of foreign and domestic policy priorities" (p. 4). In fact, irregular immigration has the potential to cause damages to all involved, including receiving and sending societies 
and migrants themselves. The roster of problems for receiving countries involves safety concerns, undesirable effects on the labor market and labor regulations, complications on foreign policy, and a generalized sense of lack of control (Papademetriou, 2005). Sending countries' concerns are with basic rights for their nationals, complications in their relationships with receiving countries, and interference in power resulting from the strengthening of human trafficking syndicates (Papademetriou, 2005). For migrants, the consequences of irregular migration can be devastating. Those victimized by human smuggling and trafficking "mortgage their very lives and futures to their smugglers" (Papademetriou, 2005, p. 4). Access to rights and assistance enabled by citizenship or other forms of legal membership is not available to non-status migrants Restrictions include access to education, health care, emergency services, employment assistance, housing, and social assistance. In fact, restrictions vary in receiving societies depending on the articulation of government-migrant groups' relationship as demonstrated in Spain and France cases cited in Triandafyllidou (2010). In Spain non-status migrants are entitled to welfare by registering at their municipality of residence. The action also prevents them to be persecuted by immigration. Non-status migrants in France are provided with medical assistance by a special program specifically created with this finality.

Problems caused by irregular migration need to be compared to the gains obtained from it. Economies of both sending and receiving countries benefit from irregular migration. Undocumented workers are believed to transfer $\$ 150$ billion in global remittances annually (Papademetriou, 2005), source that becomes increasingly important for economies of sending countries. By its turn, receiving countries benefit from irregular 
migration by being provided with workers requiring less payment, willing to work longer hours, under questionable conditions and unlikely to complaint about it. Bauder (2006) refers that "the creation of a labor force of undocumented immigrants" (p. 24) configures in an important strategy for traditional and nontraditional immigrants societies to supply a competitive labor force specially their construction and service sectors. Adding to that, Walsh (2008) sustains that reforms implemented in the immigration systems in Canada and Australia aimed to "secure exploitable labor for the lower tiers of the service economy" (p. 810) in order to prepare these countries for globalization. In the same line, Papademetriou (2005) commenting about the importance of irregular migration to the prosperity of receiving societies, contends that economic interests involved with the movement can be so significant to the point of interfering with government's will to fight the issue.

\subsection{Perspectives on Irregular Migration}

The United Nations Human Development report (UNHD, 2009) maintains that forces driving global human movements such as economic disparities and unequal $\therefore$ population growth between the North and the South are expected to continue for the next decades. This trend is associated with the expected growth of irregular migration. In order to counter this tendency, the UNHD report emphatically recommends that immigrant receiving countries reevaluate their entry policies to make them more inclusive to low-skilled workers, the ones currently left behind in the recruitment process; and also the ones willing to take unauthorized paths of entry and stay in those countries. Therefore, the number one recommendation made in the report is for "liberalizing and simplifying regular channels that allow people to seek work abroad" (p. 95), which may 
be pursued through the creation or expansion of temporary programs in sectors of "truly seasonal" (p. 96) demand, as well as by an increase in the number of visas provided to low-skilled workers in an initial temporary basis but subjected to extension or leading to a situation of permanence "at the discretion of the host government" (p. 98).

Similar opinion is expressed by Papademetriou (2005), president of the Migration Policy Institute (MPI). Predicting that irregular migration will remain a top issue in the political agenda in the near future, he argues against the exclusive use of such "law-andforce" measures as border controls, labor market regulation, police monitoring, and obstructing asylum demand to combat irregular migration. Although recognizing the necessity of such measures, Papademetriou (2005) contends that priority should be given to the expansion of legal avenues to facilitate the access of migrants, on a temporary and permanent basis, as stated below:

To deal with this reality, a school of thought is emerging that argues that channeling much illegal immigration into regulated pathways might be a more realistic course than articulating policy goals that seek total control or exclusion-goals that tend to create unrealistic public expectations and fuel further climates of intolerance (p. 4).

\subsection{Non-Status Migration in Canada}

Typically, non-status workers in Canada live in large urban centres - with Toronto alone believed to hold almost half of the population - and work in jobs despised by the domestic labour force due their safety or timing conditions (part-time, seasonal, casual) in the construction, manufacturing, and service industries (Magalhães et al., 2009). 
A range of skills and education are represented within the non-status group. For example, Magalhães et al. (2009) refer them as "educated and uneducated workers" that "fail to get past Canada's points based system which favors immigrants with particular occupational experiences, official languages fluency, and university education" (n.p.). The profile of 155 undocumented women living in Toronto registered by Pashang (2010) also reinforces the idea of diversity among non-status migrants: most of participants came from South Asia, Africa, Eastern or Central Europe, have at least a high school degree, and high knowledge of English learned before arriving.

\subsubsection{Pathways Leading to Non-Status}

Differently from United States, most of undocumented migrants in Canada enter the country by authorized means and fall out of status later by overstaying their visa conditions or when their claims for asylum are denied (Goldring et al, 2009). Goldring et al. (2009) describe several ways leading to irregular migration, including breaking up of a sponsorship relationship, having been denied asylum or refugee claims, overstaying work or student permits, and entering the country by unauthorized means. After examining several routes leading to non-status in Canada, Goldring et al. (2009) conclude that a generator role is exercised by immigration policy on irregular migration. This role would be exercised by (i) reducing opportunities for permanent residence, (ii) increasing temporary worker admissions, and (iii) limiting options to regain or gain regular status for people out of status (Goldring et al., 2009). 
Focusing on the situation of temporary farmworkers ${ }^{3}$, McLaughlin \& Hennebry (2010) argue that state policies and regulations that define conditions of employment of these workers are deemed primary responsible for "construction of precarious status and the vulnerabilities such forms of status engender" (p. 2). By emphasizing this, McLaughlin \& Hennebry (2010) seek to exempt the workers themselves for choosing to become non-status:

With very limited options and from highly constrained positions of power, migrants use whatever strategies are available to them to secure their interests, but often with difficult consequences for themselves and their families, particularly with respect to their mental and physical health (p.2).

The lack of legal and adequate channels for farmworkers transitioning from temporary to permanent condition is seen by McLaughlin \& Hennebry (2010) as the core problem leading to irregular migration. They explain that typically farmworkers are not considered for permanence, as the ones employed through the Seasonal Agricultural Workers Program (SWAP) are not entitled to apply; and the ones hired through the "Low-Skilled Pilot Project"4 (LSPP) may apply if nominated by employers in the Provincial Nominee Program (PNP). Both are criticized for "heighten[ing] worker precarity, as the workers vie for employer support and may be willing to accept unsafe work or mistreatment to get it" (p. 3). The described conditions led McLaughlin \& Hennebry (2010) to the following conclusion:

\footnotetext{
${ }^{3}$ Employed by Seasonal Agricultural Workers Program (SAWP) and Low-Skilled Pilot Project (LSPP)

${ }^{4}$ Official denomination: Pilot Project for Occupations Requiring Lower Levels of Formal Training (C and $D$ levels in the National Occupational Classification)
} 
MFWs [Migrant Farmworkers] are treated as temporary guestworkers who are not meant to stay beyond their contracts, nor to immigrate to Canada (McLaughlin \& Hennebry, 2010, p. 3).

\subsubsection{Living as Non-Status}

Emotional tolls of living without status are referred in Magalhães et al. (2009) and include permanent anxiety resulting from fear of detention/deportation, fear of becoming sick, and fear of become unemployed. Not being able to plan for the future and lacking social network are other features referred by them. 


\section{Analytical Framework: A Foucauldian Approach to Non-Status Migration}

In this section, theoretical elements from Foucault's (2003a) social theory are applied to notions of non-status migration described in the previous part. Specifically, Foucault's conception of power, objectification and discourse are used to discuss features of the movement. Although these elements appear connected in Foucault's theory they are treated separately here to facilitate both their application and understanding.

\subsection{Power}

Foucault (2003b) makes a dynamic representation of power. He invites us to think power in terms of multiple forces in action, "[as] relations of force that intersect, interrelate, converge, or, on the contrary, oppose to one another or tend to cancel each other out (p. 294). Foucault defines power as "a way in which some act on others" (p. 137). In his conception power needs to be authored by someone - it is not an abstract entity that happens by itself - what helps to think phenomenon like non-status migration in concrete terms and not as an abstract production. Another idea is that exercise of power implies the establishment of a relationship formed by a succession of actionsreactions strategically planned.

Non-status migration is associated with restrictive entry-policies of immigration in place on immigrant-receiving societies (UNHD, 2009). Processes of exclusioninclusion enacted by these policies are legitimated by the sovereignty principle that grant nation-states the right of choosing their members and, consequently, avoiding undesirable ones. The internal treatment dispensed by the Canadian government to non-status group advances the process of exclusion initiated by its entry-policy. This group is not entitled 
to essential social services and labor rights, besides being criminalized in discourse and in practice. The limitations imposed to non-status individuals in Canada impact their control over life and challenge their physical and mental health, as well as theirs family members (Landolt \& Goldring, 2010; Magalhães et al., 2009). In daily-life, power constrains impinged in the first place by the state are reproduced in other relations established between non-status workers and their employers, and with workmates or acquaintances that enjoy other citizenship status. Forces of resistance in non-status migration are represented by action of grassroots organizations on immigrants' rights.

A further important notion found in Foucault's (2003a) work is the central role that he attributes to the state as regulator of power. In contemporary societies "power relations have been progressively, governmentalized, that is to say, elaborated, rationalized, and centralized in the form of, or under the auspices of, state institutions" (p. 142) with the ultimate goal of facilitating population governance. This bio-power, has a methodical nature. It seeks "to administer, optimize, and multiply it [life] by subjecting it to precise controls and comprehensive regulations" (p. 259). Bio-power manifests itself through classificatory, orderly and control procedures that are impinged in the management of matters related to the population such as public health, housing, migration, life expectancy, and birth and mortality rates.

Another sphere of action of bio-power conceived by Foucault is to discipline citizens. This task is forged by social institutions and has the ultimate goal of producing subordinated citizens aligned with social and economic objectives of the state. The historic consequence of this systematic and methodic form of governance was the 
generation of a "normalizing society" (p. 266) in which economic processes and relations of domination were reproduced (Foucault, 1984).

The "order" forged by bio-power is totally disrupted with non-status migration. The idea of individuals that inscribe themselves in an autonomous manner and without having legal authorization for it totally opposes to the spirit of bio-power. In this context, non-status individuals are promptly identified as "deviant" and permanently seen as “"remaindering' other of the system, an extra but not a surplus" (Lee, 2010, p. 332). The merit of non-status migration, according to Lee (2010), is to expose the inflexibility of current legalistic category of citizenship, opening up the query for other forms of citizenship. Lee: (2010) also perceives the categorization made in citizenship a manifestation of bio-power in its work' of "facilitating modern liberal governance in ensuring the normalized mundane reproduction of social life in a 'proper' form and 'proper' way"' (p. 331). Bio-power executes it by providing a script of ideal citizen embedded in social institutions and attempting to "reproduce domesticated subjects who will be settled and kept in place, thus reducing the possibility and potency of critical dissents and deviant transgression" (p. 332).

However, irregular migration is a paradoxical issue: at the same time that it is publically condemned, the movement is encouraged in industrial societies, as was previously seen. Therefore, with irregular work already incorporated into developed economies, bio-power now is employed to sustain the vulnerability of the undocumented population by denying them civic and employment rights and by avoiding the creation of legal alternatives for the movement. Bauder (2006) well captured the idea by pointing out that "migrant and immigrant workers are valuable because they are vulnerable" (p. 22). 


\subsection{Processes of Objectification}

Ransome (2010) has the opinion that individuals as social actors enjoy little "biography or autonomy" (p. 257) in Foucault's theory, Such lack of agency goes even further in the processes of objectification conceived by Foucault. He states that through practices of categorization (e.g., good and bad immigrant; legal and illegal; immigrants and non-immigrants) minority groups have their representation politically constructed in a way to justify their subjugation and social exclusion. The process is called "objectifying" because it does not acknowledge individuals and their humanity; it rather imposes a "new identity" that "categorizes the individual, marks him by his own individuality, attaches him to his own identity, imposes a law of truth on him that he must recognize and others have to recognize in him" (Foucault, 2003a, p. 130).

Foucault's idea of objectification is identified in the conception of "cultural representations" described in Bauder (2006): "judgments that associate people with distinct characteristics and qualities and assign them to particular social and economic roles". (p. 29). Applied to immigrants, constructed representations have the capacity to shape and legitimate labor practices toward these workers as well as to influence attitude towards them. Bauder (2006) comments that "feelings of abjections" (p. 30) directed to refugees, asylum seekers, and illegal immigrants in many industrialized countries, have the effect to devaluate these foreign workers and subordinate them to non-migrant workers "although both groups may posses the same ability and skill to perform a given job or complete a given task". (p. 30). A similar situation is observed in Canada where the representations of non-status migrants is mostly made in negative terms, associating these people with criminality, dubious character, and a threat to others (Nyers, 2010) and rarely 
portraying them as "fully formed subjects who are capable of autonomy, selfrepresentation, and claim making" (Nyers, 2010, p. 132). Such representations endorse measures of persecution applied against the group at the same time that justify inaction of the government.

\subsection{Discourse}

Discourses can be defined as "the prevailing mode and manner of accounts and conversations that go on in society and that make one historical period distinguishable from another" (Ransome, 2010, p. 249). During the development of his work, Foucault transited from a conception of discourse representative of the world, a verbal/textual representation of the exterior social reality and the power-play implied on it, to a more influential form where discourse (i.e., "discursive practice") is conceived as part of reality, a reality that is shaped by the discourse in formation and by a particular way of seeing the world (Ransome, 2010). Therefore, discourses have the ability of shaping perceptions and defining attitudes. Due to its active role in the production of the social reality, discourses are also considered a mechanism of production of power. Ransome (2010) explains how power operates on discourses:

Discourses and the intellectual paradigms or épistèmes of particular periods that they make up, represent one such manifestation of power. They exercise power not just on the intellectual plain of thoughts, ideas and meanings (...), but also in a much more concrete and physical sense because these ideas become inscribed into the material practices and institutions of the society (p. 256).

The association of discourse and power in Foucault's theory assumes that discourses in society are mostly produced by those in privileged positions within society. 
It is also assumed that discourses manifest and are interested in keep the social order established by the majority. Therefore, through discourses, "status quo" is maintained and reproduced through a mechanism explained in Ransome (2010):

The orthodox majority of the population seeks control over the deviant minority not just because it controls the discourse through which these individuals and groups become defined as deviant, but because the same attitude of mind becomes embedded in the political, cultural and legal institutions of society (p. 256).

The polarized positioning that nonstatus migration raises can be explained by the political circumstances involved in the issue. Non-status migration challenges the selfgranted right of nation-states to choose their occupants. The movement is reacted by incriminatory representation of its members made by nation-states that, in this way, set the stage for power measures applied against this group, following the contended by Walsh (2008): "States may not be able to prevent unauthorized entries, but they still exert the capacity to construct and enforce categories of 'illegality', which have very real social consequences" (p. 790). 


\section{Research Methods}

My first contact with the topic developed in this paper happened two years ago during transcription of interviews of people without status living in Canada, for a research project. At that time I remember being disturbed by the contrasting realities of those interviewed and the common public perception of them as "civic offenders". These people seemed to be living their lives and making their choices aiming the best for themselves and for their families, the same kind of aspirations held by most people. However, their conditions were marked by constrains and sometimes irremovable obstacles such as the lack of legal alternatives to permanently stay in Canada. What struck me the most while listening to their stories was their image/treatment as offenders when, in fact, I saw them as victims of a system that had excluded them by deeming them unfit as immigrants.

Since that first contact with the topic I have been interested in and searched the literature, and I came across the CIMM Report with the description of the CIMM study on undocumented and temporary workers, and its findings and recommendations. It represented a rare opportunity to observe in the official realm an open discussion on irregular migration. The CIMM Report led to other related materials: minutes of meetings from the data gathering phase of the CIMM study, and the reply to the CIMM Report offered by the government (Government of Canada Response, 2009). These three elements compose the totality of documents researched in this paper. They are public documents available online and will be presented in more details over the next section of this paper. They were chosen due to their potential as parts of the same process (the 
CIMM study on temporary and undocumented workers) to reveal the dynamic behind the official representation of non-status workers, a perspective explored in this paper.

The qualitative text analysis in the above mentioned documents follow recommendations found in Silverman (2000):

\begin{abstract}
(...) The distinctive contribution qualitative researchers can make is in utilizing their theoretical resources in the deep analysis of small bodies of publicly shareable data. This means that, unlike many quantitative researchers, we are not satisfied with a simple coding data. Instead, we have to work to show how the (theoretically defined) elements we have identified are assembled or mutually laminated (p. 828).
\end{abstract}

Silverman (2000) also alerts to the importance of having a well defined analytical approach as well as to work on a limited amount of data on qualitative analysis. Therefore, the next steps of the study will refer to the establishment of the analytical framework and the definition of data selection criteria. Regarding the first aspect, the choice fell upon Foucault and elements of his social theory. His dynamic conception of power and the special role attributed to the state as power regulator was a good fit to non: status reality. Moreover, his notion of objectification/social representation of minority groups well applies to undocumented group. The role attributed to discourse as a powerful way of building perceptions and define attitudes in Foucault's theory was central to explain both the weight of a negative representation on the lives of non-status migrants as well as the objectives aimed by the government sustaining/building such representation.

As per the second aspect - the definition of criteria for data selection - I established a thematic analysis privileging the discourse by politicians and government representatives on undocumented workers and on low-skilled temporary workers. The 
selection of texts/quotes represented in this paper follows this thematic coding. Exemplifying this, only material from minutes of the CIMM first meeting were selected to be part of this paper due its representation of the official discourse on non-status workers. In this meeting, high-ranked government representatives discussed relevant policy and responded to questions from CIMM members who also had the opportunity to position themselves on the issue. This meeting was considered the best example from all 18 meetings hold by CIMM following the criteria established for thematic coding. The same process applied to the selection of texts within the CIMM Report and the Government Response documents. 


\section{Analysis}

\subsection{Preliminaries of the CIMM Study}

Standing Committees are permanent groups formed by representatives of the Parliament and established by Standing Orders of the House of Commons. They follow specific mandates designated by the House which involve the assessment of expenditures and activities, budgetary planning, and policy development of a specific government department or agency. Committees may also study issues of their own interest. Currently, there are 28 Standing Committees in the House of Commons (Parliament of Canada, 2011). The Standing Committee on Citizenship and Immigration (CIMM) apart from other designations determined by the House, has the special mandate to examine and report matters related to the mandate, management and operations of the Citizenship and Immigration Canada (CIC) and the Immigration and Refugee Board (IRB) (Parliament of Canada, 2011).

The study on undocumented and temporary foreign workers was adopted by CIMM on November 2007 and initialized on February 2008. It was developed during the $39^{\text {th }}$ Parliament. A final document reporting findings and recommendations of the study was delivered to the House of Commons on May 2009 during the $40^{\text {th }}$ Parliament. Change of Parliament led to changes in the CIMM composition too. CIMM members ${ }^{5}$ during the execution phase of the study were not the same signing the final report. Half of

\footnotetext{
${ }^{5}$ Norman Doyle (Chair), Thierry St-Cyr, Andrew Telegdi, Dave Batters, Colleen Beaumier, Maurizio Bevilacqua, Robert Carrier, Olivia Chow, Nina Grewal, Jim Karygiannis, Wajid Khan, and Ed Komarnicki. Eventual substitutions were made by acting members from the same political party
} 
the twelve members were replaced from the initial formation ${ }^{6}$ strengthening the conservative representation (i.e., from 5 to six members) at expense of liberals (i.e., from 4 to 3 members). This alteration may have been a factor in the CIMM lack of consensus to support a program of regularization to non-status workers.

The CIMM study created an immense volume of information on temporary foreign workers and programs and on non-status migrants/workers through the testimony of experts, government authorities, activists, and representatives of workers, employers, migrants' associations, industry directors, and migrants themselves. Approximately 52 panelists presented for Committee members and were questioned by them during the 18 meetings held by the CIMM with the purpose to understand the issues investigated in the study. Also, hundreds of written briefs from diverse organizations and industries were sent to the CIMM during the development phase, signaling the importance of the issues addressed by the study.

\subsection{First Meeting: Official Discourse \& Party Ideologies}

x. In the inaugural session of the CIMM study on temporary and undocumented workers the subjects were explored from a policy perspective. Federal authorities from the Citizenship and Immigration Canada (CIC), Canada Border Services Agency (CBSA), and Human Resources and Social Development Canada (HRSDC) presented to CIMM members. Les Linklater, Director General of the CIC stressed the integrated efforts of the three departments on the conduction of the Temporary Foreign Workers

\footnotetext{
${ }^{6} \mathrm{CIMM}$ formation that presented the report: David Tilson (Chair), Maurizio Bevilacqua, Thierry St-Cyr, Paul Anthony Calandra, Olivia Chow, Rick Dykstra, Nina Grewal, Jim Karygiannis, Alexandra Mendes, Eve-Mary Thaï Thi Lac, Alice Wong, and Terence Young.
} 
A diverse approach to irregular migration was observed in the participation of Liberal and New Democratic representatives. Overall sympathetic to issues faced by migrant workers and well informed about immigration policy and programs, they hold a view of irregular migration as resulting from past policy changes and current gaps in the immigration system. Comments from liberal MP Andrew Telegdi well illustrate this vision. Heavily critical of the point system, Telegdi attributed the changes implemented in the points system to the current problems with shortage of labor and irregular migration:

The low-skilled folks are the ones who were eliminated as possible immigrants to Canada at the time the point system changed (CIMM-13, p. 4).

And also,

The problem is that the system is not very functional, and that's why there's such a huge shortage. (...) And it comes back to the point system. Skilled trades have a hard time coming in. Labourers have a hard time coming in (CIMM-13, p. 4).

Referring to the impossibility of temporary farmworkers to apply for permanent status, Telegdi commented:

If we're going to have people the economy needs, it would be preferable to have them be Canadian citizens, rather than have them be here, be put out, and be brought back for that many decades (CIMM-13, p. 13).

And he compared the current situation with the hiring of Chinese migrants in past immigration history: 
It reminds me of the old days when we brought the Chinese to build the railway and then put in place the Chinese Exclusion Act. There is something wrong with that (p. 13)

Another heavy critic of the current immigration system was the NDP representative Olivia Chow. A point emphatically questioned by her was about the categories of workers targeted for permanence by current and planned programs:

Given that at least half the workers in the temporary foreign worker program are the low-skilled workers, the categories $\mathrm{C}$ and $D$ rather than A and B, why wouldn't you structure your experience class in a way that at least you give those who are not highly skilled with degrees, with fluent English or French, a chance that they could actually stay in Canada or apply in Canada? (CIM-13, p. 17)

And also referring to low-skilled workers, she argued:

I believe if they're good enough to work here, probably most of them should be good enough to stay here (CIMM-13, p. 18).

Bloc Québecois $(\mathrm{BQ})$ representatives revealed a neutral approach toward irregular migration. They were basically interested to know "how the system works" and posed questions about migrant rights, the volume of migrants, and mechanisms in place to control their entry and departure. Their interventions led sometimes to interesting conclusions as, for example, when Robert Carrier (BQ) after being informed by CIC Director about the non-existence of systematic monitoring to ensure that migrant workers leave the country after work permit expiration, commented: "Therefore, this is a good climate for undocumented workers" (CIMM-13, p. 17). 


\subsection{CIMM Report}

The Report of the Standing Committee on Citizenship and Immigration (thereafter CIMM Report) (2009) is a 79-page document generated from evidences and discussions provided during the assessment phase of the CIMM study. It describes main findings about the situation of temporary and undocumented workers and offers 36 recommendations aiming the improvement of programs. The document is organized in two parts. The situation of foreign workers and TFWP is analyzed in the first part which covers almost the totality of the document. The second part, with only six pages, addresses the situation of undocumented workers. In it, difficulties faced by this group of migrants in terms of vulnerability is presented:

Fear of being reported to the authorities leads some non-status workers to tolerate substandard working conditions (p. 48).

It also recognizes the contribution of non-status workers to the economy:

We recognize that these people are contributing to our society by filling a labor need that is not being met domestically (p. 49).

Most importantly, the document understands irregular migration as resulting from scarce opportunities available for certain group of migrants:

We understand that in many cases, these people were failed by our immigration system that provided them with no realistic opportunity to immigrate to Canada legally (p.49).

We need to ensure that we have an efficient economic immigration system that is responsive to Canada's actual labour needs. The workers we need here in a long-term basis must be able to immigrate here legally on a permanent basis from the start (p. 52). 
Despite this understanding, the view of some CIMM members was that a program of regularization would be unfair with "hundreds of thousands of people are patiently waiting years to legally call Canada home" (CIMM Report, 2009, p. 48) and could have the undesirable effect of bringing more irregular migrants to the country. This line of thinking prevented the CIMM from supporting a regularization program in its report. Unable to reach a consensus regarding the situation of current irregular migrants, CIMM members opted for finding "practical means" to attenuate the problem. They suggested the following measures in The Report (2009): (i) review of the point system to make it more inclusive of different skill levels; (ii) increase the efficiency of the Provincial Nominee Program (PNP) as a pathway for permanence of temporary workers; and (iii) create a channel for TFWs transition to permanent residency as happened in the Live-in Caregiver Program (LCP). The two last propositions were formalized in Recommendation \#3 and \#6 respectively in the CIMM Report and are presented bellow:

Recommendation \#3: "The committee recommends that the Government of Canada initiate dialogue and facilitate cooperation with the provinces and territories, so that the temporary foreign worker and provincial nominee programs function together smoothly to provide a pathway to permanent residency (CIMM Report, 2009, p. 56).

Recommendation \#6: The Committee recommends that the Government of Canada create a path to permanent residency for all temporary foreign workers modeled on the opportunity currently available to live-in caregivers (CIMM Report, 2009, p. 56). 


\subsection{Government Response}

In a 12-page document titled Government of Canada Response to the Report of the Standing Committee on Citizenship and Immigration: Temporary Foreign Workers and Non-Status Workers (thereafter referred as Government Response), the government replies to the recommendations made by the CIMM. Initially the document identifies the scope of Temporary Foreign Worker Program (TFWP) as to provide for shortterm/temporary needs in the national labour market; needs unable to be fulfilled by domestic sources. The "overuse" (p. 2) of TFWP is recognized in the Government Response, identified by the "growing volumes" of the program. Curiously, however, this distortion is attributed to difficulties faced by employers on accessing "skilled permanent residents" (p. 2), and the correction of the problem is seen to be achieved through initiatives implemented by the government with the goal to: “improve employers' access to skilled permanent residents and thereby lessen the reliance on the TFWP" (p. 2). The measures included the prioritization of applicants in the economic class after 2008 and the creation of the Canadian Experience Class (CEC) program. CEC is described in the Government Response on the following terms:

The CEC facilitates the transition to permanent residence for international students and TFWs [Temporary Foreign Workers] who possesses skilled work experience in Canada, have sufficient knowledge of English or French and may have earned a Canadian educational credential. Indeed, research has demonstrated that these factors facilitate the integration and movement of new immigrants in the labour market. (Government Response, 2009, p. 2).

The statement above partially responds to the request made in the CIMM Report for implementation/improvement of pathways leading to permanent residency "for all 
temporary foreign workers" (CIMM Report, Recommendation \#6, p. 56). It limits the qualified TFWs to students and skilled workers. The opportunity for low-skilled migrants to apply for residence was denied and justified in the following terms in the Government Response (2009):

\begin{abstract}
(...) lower-skilled workers generally have limited training, transferable skills and linguistic abilities, which mean adapting to changing conditions and finding their way around in the Canadian labour market, could be more of a challenge. Moreover it does not appear that a broad-based long-term need for lower-skilled workers exists across Canada to the same extent that experts and stakeholders have identified for skilled workers. Nevertheless, where provinces and territories have identified them as sectoral and regional priorities, pathways to permanent residence for lowerskilled workers exist through the PNP [Provincial Nominee Program] (p. 2).
\end{abstract}

The above statement reveals some tendencies of the current immigration policy in Canada. First, the alleged inability of low-skilled migrants in adapting to the labour market is the counterpart of a policy that presents the ideal immigrant as skilled and educated. This ready-to-go prototype of immigrant does not require investments in public policy (integration, settlement), education, training, or language and is unlikely to become a "social problem" for presenting conditions (employment, education) similar to the mainstream population. Second, the interpretation made by the government regarding the increased use of TFWP differs from what was pointed out in the evidences phase of the CIMM study and by the CIMM report itself. Instead of attributing the distortion of TFWP use to an inefficiency of the current immigration system (the point system, with no transition from temporary to permanent conditions the government interpreted it as a labour market need for permanent "skilled workers", as was referred in the initial part of this section. Third, the government is delegating the initiative of sponsoring new 
immigrants to the private sector, especially in the lower-skill levels ${ }^{7}$ of the National Occupational Classification (NOC) through the Provincial Nominee Program (PNP), a movement that has been criticized (McLaughlin \& Hennebry, 2010; Valiani, 2010) for excessively rely on employer-employee relationship, increasing the possibility of exploitation and abuse.

Only a small part of the Government Response is dedicated to a response to CIMM conclusions on non-status workers. There, in spite all aspects brought up in the CIMM report (contributions of workers, lack of legal pathways leading to permanence), only the pertinence of a regularization program is discussed, as seen below:

The situation of undocumented workers is a continuing concern for many nations, including Canada. The Government of Canada recognizes that some of these workers may be vulnerable to exploitation and economic downturns and that some stakeholders see their potential for addressing labour market needs. However, as pointed out by the Committee, options for regularizing these nonstatus workers, while at the same time maintaining program integrity, are limited. There are a number of legitimate avenues for foreign workers to enter the Canadian labour market. Regularizing those who failed to respect the terms and conditions of the program and remained in Canada through illegal avenues would be unfair to all permanent resident applicants who have followed the proper process and are waiting to have their application processed (Government Response, 2009, p. 11)

A misleading claim made in the above statement is that non-status workers have several "legitimate avenues to enter the Canadian labour market". While this applies for temporary situations, it is not true for permanent opportunities. As discussed above, it is known that almost no channels exist for low-skilled workers to remain in Canada after expiration of their temporary work permit. TFWP for low-skilled migrants such as those

\footnotetext{
${ }^{7}$ Levels "C" and "D" in the NOC
} 
in the Low-Skilled Pilot Project, and Seasonal Agricultural Workers Program, do not lead to permanent residency. The transition from Provincial Nominee Program (PNN) and permanent residency is questionable. McLaughlin \& Hennebry (2010) observe that farmworkers are not usually nominated through the PNN:

(...) the use of this program merely serves to heighten worker precarity, as the workers vie for employer support and maybe willing to accept unsafe work or mistreatment to get it" (p. 3).

Assessing the performance of the PNN by comparing the numbers of TFWs with the numbers of permanent residents through the PNN shows the lack of mobility between these programs. Taking the year of 2009 for example, while the numbers of TFWs in Ontario, B.C. and Alberta were 94,750,69,993, and 65,671 respectively (CIC, 2009), the respective number of permanent residents created through the PNN in the same provinces were $1,271,4,708$, and 5,325 respectively (Annual Report to Parliament, 2010). Another idea implied in the text is that people would choose to remain in Canada without legal status because of their unwillingness to wait for their application to be processed. Although this may apply to some cases, the literature suggests that typically non-status individuals lack options for legally staying in Canada. For example, McLaughlin \& Hennebry (2010), explain that farm workers in temporary worker programs wishing to stay in Canada have to become non-status as "no direct pathway between years of work and gaining citizenship status exists for this class of workers [SAWP and LSPP ${ }^{8}$; nor do they generally qualify under the immigration point system" (p.7). Similarly, Magalhães et al. (2009) note that non-status workers employed in the construction industry "fill this respective labour shortage, but fail to get past Canada's points based system which favors

\footnotetext{
${ }^{8}$ Seasonal Agricultural Workers Program and Low-Skilled Pilot Project
} 
immigrants with particular occupational experiences, official languages fluency, and university education" (n.p.). The idea that a non-status worker "jump the line" is further refuted by No-One is Illegal (2010): "Most of the non-status immigrants are skilled or semi-skilled workers who do not qualify under our point system so there is no queue for them." Further:

Visit any construction site, restaurant kitchen or downtown office tower after hours when the cleaning crew springs to action, and odds are you'll be sharing space with non-status workers. However, as working class immigrants, the majority don't qualify for permanent status due to Canada's exclusive immigration policies (Portuguese-Canadian National Congress, 2009, p. 2). 


\section{Discussion and Conclusion}

This paper examined the discourse following the CIMM study on undocumented and temporary workers. More specifically, the situation and representation of undocumented workers was examined. An overview of the process indicates a preponderance of a conservative approach by government and political representatives on the undocumented issue. Notably, evidences gathered during the phases of assessment of the study pointed to a permanent labour deficiency for all kinds of skills - not only for skilled and educated workers! The relationship between this need and the increased reliance on temporary and non-status work was the premise for the CIMM to have been made responsible by the House of Commons, for a study on undocumented and temporary workers and was later on ratified in the CIMM Report. Despite the preponderance of actual evidence in the process, the interpretation given by the government followed a different line. By stating that the overuse of the TFWP signals a high demand for permanent skilled workers, the government not only corroborated its "skilled immigrant" policy as well as found a way to circumvent the changes proposed by the CIMM, to facilitate the transition of temporary workers to permanence in Canada. It is in the representation of low-skilled workers that the official discourse on non-status workers starts to be delineated. By holding on to its high-skilled immigrant policy and justifying the non inclusion of low-skilled migrants based on their presumed language, educational and professional deficiencies, the government reinforces a stereotypical labour valorization and sets terrain to deny any provision to assist workers out-of-status, as they supposedly belong to the same low-skilled category of temporary foreign workers. This observed high skilled/low-skilled dichotomy becomes embedded."into the 
material practices and institutions of the society" (Ransome, 2010, p. 256) and it is a way of state to exercise power. The resemblance of the current inclusion/exclusion criteria on skills to past practices of immigration restrictions based on ethnicity, religion and cultural values (Abu-Laban \& Gabriel, 2002) is inevitable. At minimum, it is a precarious social move for a country that so heavily relies on immigrants and on immigrant labour.

Regarding specifically the undocumented movement, divergent perceptions of Committee members could not be harmonized towards support of a regularization program. Despite that, certain compromise was observed in the measures suggested by the Committee to curb the growth of irregular migration. However, even those lacked general agreement, evident in the "supplementary" note added to the CIMM Report (2009) the Conservative members where they "respectfully dissent from recommendations 3 and $6 "(p .75)$ that propose creation of transitioning pathways between temporary programs and permanent residency. The lack of consensus between CIMM members was noted in the official reply. Not only did the government feel unobligated to justify or respond to any aspect raised in the CIMM Report but was also able to sustain its misleading argument that undocumented workers take the place of prospective immigrants and that they do not deserve to be granted status. It was the same argument presented by Les Linklater, the CIC General Director, in the CIMM inaugural meeting, referred in the analysis section of this paper. This fact, besides validating Foucault's perception that discourse is produced by people in power positions in society, also calls into question the validity/importance of the implementation of an expensive and prolonged process such as the one developed by the CIMM study. 
In the earlier theory section, the key terms of discourse, objectification, and power were introduced. The results of this study are clearly in keeping with Foucault's' ideas about (bio-)power. Additionally, the study also demonstrates the process of objectification experienced by non-status workers. In the end, state actions expressed in official discourse turn non-status workers into an undesirable category, despite their obvious and widely demonstrated usefulness to the economy. While there were disagreements throughout the official process, between different social actors, in the end, the state exerted its power of defining its citizenry through the negative labeling of its opposite, the non-citizenry. 


\section{References}

Abu-Laban, Y. \& Gabriel, C. (2002) Selling Diversity: Immigration, Multiculturalism, Employment Equity and Globalization. Peterborough, ON: Broadview Press.

Bauder, H. (2006). International Segmentation of Labor. In Labor Movement: How Migration Regulates Labor Markets. New York: Oxford University Press, pp. 19-34.

Bauder; H. (2008). Citizenship as Capital: the Distinction of Migrant Labor. Alternatives, 33: 315-333.

Berinstein, C. et al. (2006). Access Not Fear: Non-Status Immigrants \& City Services. Report. http://www.tsci.ca/files/ET_Readings/Access_Not_Fear

Bernhard, J.K. et al. (2007) Living with Precarious Legal Status in Canada: Implications for the Well-Being of Children and Families. Refuge, 24 (2): 101-114.

Canada Immigration and Citizenship (CIC): Facts and Figures 2009: Foreign Workers

Present on December 1st by Gender and Occupational Skill Level.

http://www.cic.gc.ca/english/resources/statistics/facts2009/temporary/12.asp

CIMM-13 (2008): Standing Committee on Citizenship and Immigration. Evidence Number 013. House of Commons Committees. Parliament of Canada. Retrieved from

http://www.parl.gc.ca/HousePublications/Publication.aspx?DocId=3296997\&Langua ge $=\mathrm{E} \&$ Mode $=1 \&$ Parl $=39 \& S e s=2$

Citizenship and Immigration Canada (CIC): Annual Report to Parliament on Immigration 2010. Table 8: Permanent Residents Admitted in 2009, by Destination and Immigration Category. Retrieved from http://www.cic.gc.ca/English/resources/publications/annual-report2010/section3.asp

Ettinger, P. (2009) Imaginary Lines: Border Enforcement and the Origins of Undocumented Immigration, 1882-1930. Austin: University of Texas press.

Foucault, M. (2003a). The Subject and the Power in The Essential Foucault. Paul Rabinow \& N. Rose (ed.) New York: The New Press.

Foucault, M. (2003b). Society Must be Defended in The Essential Foucault. Paul Rabinow \& N. Rose (ed.) New York: The New Press. pp. 294 - 299.

Foucault, M. (1991). Politics and the Study of Discourse in The Foucault Effect: Studies in Governmentality, Burchell, G.; Gordon, C., and Miller, P. (ed.), Chicago: The University of Chicago Press.

Goldring, L. et al. (2009). Institionalizing Precarious Migratory Status in Canada. Citizenship Studies, 13 (3): 239-265.

Government of Canada Response to the Report of the Standing Committee on Citizenship and Immigration: Temporary Foreign Workers and Non-Status Workers (2009) Parliament of Canada. Publications: Government Response. Retrieved from 
http://www.parl.gc.ca/HousePublications/Publication.aspx?DocId=4017803\&Langua $\mathrm{ge}=\mathrm{E} \& \mathrm{Mode}=1 \& \mathrm{Parl}=40 \& \mathrm{Ses}=2$

Hennebry, J. (2010) Private Interests in Canada's immigration System. Presented at the workshop on "Global Picture Local Snapshots". Permanently Temporary: Temporary Foreign Workers and Canada's Changing Attitude to Citizenship and Immigration Symposium. Social Planning Toronto, OCASI, CERIS. Toronto.

Kapur, R. (2003) The "Other" Side of Globalization: The Legal Regulation of CrossBorder Movements. Canadian Woman Studies, 22 (3/4): 6-15.

Khandor, E.; McDonald J.; Nyers, P. \& Wright, C. (2004) The Regularization of NonStatus Immigrants in Toronto: Past Policies, Current Perspectives, Active Campaigns. http://www.ocasi.org/status/Regularization_booklet.pdf

Lee, C. (2010). Undocumented Workers' Subversive Citizenship Acts. Peace Review, 20 : 330-338

Lowry, M. \& Nyers, P. (2003). "No One is Illegal": the Fight for Refugee and Migrant Rights in Canada. Roundtable Report. Refuge, 21 (3): 66-72.

Magalhaes, L.; Carrasco, C. \& Gastaldo, D. (2010) Undocumented Migrants in Canada: A Scope Literature Review on Health, Access to Services, and Working Conditions. Immigrant Minority Health, 12 (1): 132-151.

McLaughlin, J. \& Hennebry, J. (2010) Pathways to Precarity: Structural Vulnerabilities and Lived Consequences in the Everyday Lives of Migrant Farmworkers in Canada. Presented at the workshop on "Producing and Negotiating Precarious Migratory Status in Canada." York University, Toronto: Research Alliance on Precarious Status http://www.yorku.ca/raps $1 /$

Menjívar, C. \& Kil, S. (2002) For Their Own Good: Benevolent Rhetoric and Exclusionary Language in Public Officials' Discourse on Immigrant-Related Issues. Social Justice, 29(1-2): 160-176.

No-One Is Illegal -Toronto (2011): Myths and Realities of the Immigration System http://toronto.nooneisillegal.org/node/ 15

Nyers, P. (2005) The Regularization of Non-Status Immigrants in Canada: Limits and Prospects. Canadian Review of Social Policy, 55: 109-115.

Nyers, P. (2010) No One Is Illegal Between City and Nation. Studies in Social Justice, 4 (2): 127-143.

OCASI (2006) Status Campaign: Proposal for the Regularization of Individuals and Families Without Status. http://www.ocasi.org/downloads/STATUS_Regularization_Proposal_Jun06.pdf on March 01, 2011.

Papademetriou, D. (2005). The Global Struggle with Illegal Migration: No End in Sight. ${ }_{1, \ldots}{ }^{i}$. Migration Policy Institute. http://www.migrationinformation.org) 
Parliament of Canada (2011): House of Commons Committees. Retrieved from http://www.parl.gc.ca/CommitteeBusiness/AboutCommittees.aspx?Language=E\&M ode $=1 \&$ Parl $=41 \&$ Ses $=1$

Pashang, Sohelia (2010) Experiences of Non-Status Women in Panel 3: Social Impacts and Labour Response to TFWs. Permanently Temporary: Temporary Foreign Workers and Canada's Changing Attitude to Citizenship and Immigration Symposium. Social Planning Toronto, OCASI, CERIS. Toronto.

Portuguese-Canadian National Congress (2009) Moving Towards Visibility. Non-Status Immigrants and the Social Service Sector. The Undocumented Support Network Project: Toronto, ON. http://www.library.yorku.ca/e/resolver/id/1855711.

Rabinow, P. (ed.) (1984). Introduction In: The Foucault Reader. New York: Pantheon Books. pp 3-29

Ransome, Paul (2010). Discourse and Power: Post-Structuralist Social Theory (Chapter 10) In: Social Theory for Beginners. Bristol: The Policy Press.

Report of the Standing Committee on Citizenship and Immigration: Temporary Foreign Workers and Non-Status Workers. (2009). House of Commons Canada.

Retrieved from

http:/www.parl.gc.ca/content/hoc/Committee/402/CIMM/Reports/RP3866154/cimm rp07/cimmrp07-e.pdf

Rousseau, C. et al. (2008). Health Care Access for Refugees and Immigrants with Precarious Status: Public Health and Human Right Challenges. Revue Canadienne de Sante Publique, 99 (4): 290-292.

Silverman, D. (2000) Analyzing Talk and Text in Handbook of Qualitative Research. Second Edition. Denzin, N. \& Lincoln, Y. (ed.). Sage Publications, pp. 821-834. .

Triandafyllidou, A. (2010) Irregular Migration in Europe in the Early $21^{\text {st }}$ Century in Irregular Migration in Europe: Myths and Realities. Hellenic Foundation for European and Foreign Policy (ELIAMEP) and Democritus University of Thrace, Greece.

United Nations Human Development Report (UNHDR) (2009) Overcoming Barriers: Human Mobility and Development. Edited by United Nations. http://hdr.undp.org/en/media/HDR 2009 EN Chapter5.pdf

Valiani, S. (2010) The Rise of Temporary Migration and Employer-Driven immigration in Canada: tracing Policy Shifts of the Late $220^{\text {th }}$ and Early $21^{\text {st }}$ Centuries. Presented at the workshop on "Producing and Negotiating Precarious Migratory Status in Canada." York University, Toronto: Research : Alliance on Precarious Status http://www.yorku.ca/raps1/

Walsh, J. (20088). Navigating Globalization: Immigration Policy in Canada and Australia, 1945-2007. Sociological Forum, 23 (4): 786- 812.

Wright, C. (2003). Moments of Emergence: Organizing By and With Undocumented and Non-Citizen People in Canada After September 11. Refuge, 20 (3): 5 -15 